\title{
The microbial loop in the Red Sea: dynamics of pelagic bacteria and heterotrophic nanoflagellates*
}

\author{
Thomas Weisse \\ Limnological Institute, University of Constance, PO Box 5560, 7750 Konstanz, Federal Republic of Germany
}

\begin{abstract}
Growth and grazing experiments with free-living bacteria and nano- and microzooplankton were conducted in February-March 1987 in the central Red Sea and the Gulf of Aden using metabolic inhibitors. Results demonstrate the existence of a dynamic 'microbial loop' which dominates the pelagic system in terms of biomass and production. In the epipelagial, bacterial abundance ranged from 5.2 to $8.8 \times 10^{5}$ cells $\mathrm{ml}^{-1}$, and heterotrophic nanoflagellate (HNF) abundance from 0.6 to $1.2 \times 10^{3}$ cells $\mathrm{ml}^{-1}$. Bacterial growth rates varied between 0.014 and $0.097 \mathrm{~h}^{-1}$, grazing rates between 0.010 and $0.108 \mathrm{~h}^{-1}$ Population grazıng rates corresponded to 2.0 to $5.4 \times 10^{4}$ bacteria consumed $\mathrm{ml}^{-1} \mathrm{~h}^{-1}$ Bacterial biomass, growth and grazing rates were higher in the central Red Sea than in the Gulf of Aden. Bacterial growth was inversely related to grazing pressure. HNF were the major bacterial consumers with average ingestion rates of 29 bacteria $\mathrm{HNF}^{-1} \mathrm{~h}^{-1} \mathrm{HNF}$ production was controlled by microzooplankton predation. Net growth rates of bacteria and HNF were also negatively coupled and exhibited considerable temporal variation. There was also some indication for diurnal rhythms of bacterial growth and grazing loss rates. At night, grazing impact on bacteria was reduced to less than half the noon value. The temporal variations observed caution against extrapolations derived from routine experiments run at fixed hours.
\end{abstract}

\section{INTRODUCTION}

A considerable amount of phytoplankton primary production is released via exudation as dissolved organic material (DOM) in marine ecosystems. The DOM pool, which is further replenished by zooplankton excretion, 'sloppy feeding' (Lampert 1978) and allochthonous input, is used by pelagic bacteria for their biomass production. It has now generally been accepted that heterotrophic bacteria process a substantial amount of phytoplankton production in marine areas (see Cole et al. 1988 for review). The bacterial secondary production enters the marine food web by grazing through phagotrophic protozoa and, to a smaller extent, copepods and mucus net feeders (Azam et al. 1983). Heterotrophic picoflagellates ( 0.2 to $2 \mu \mathrm{m})$ and nanoflagellates ( 2 to $20 \mu \mathrm{m}$, according to Sieburth

\footnotetext{
- This paper is dedicated to the memory of Annette Barthelt Marco Buchalla, Hans-Wilhelm Halbeisen and Daniel Reinschmidt, who were killed by terrorist action during the 'Meteor' cruise
}

et al. 1978) are currently thought to be the main consumers of bacterial production in aquatic ecosystems (Sherr \& Sherr 1984, Porter et al. 1985, Fenchel 1987). These small heterotrophic flagellates (HNF) may form an important food source for larger protozoans as well as for metazoans. However, the extent and pathways of transfer of microbial production to higher ranked consumers in marine food webs are still largely unknown (E. B. Sherr et al. 1986). From a theoretical point of view the 'microbial loop' (Azam et al. 1983) should be of special importance in oligotrophic areas with a high energy input and a rapid cycling of organic matter between the different system compartments. As in these ecosystems input of new nutrients is small, primary production is largely based on regenerated nutrients (Dugdale \& Goering 1967, Eppley 1981). Accordingly, the DOM must be channeled through the microbial loop complex to the higher trophic levels because otherwise a permanent loss of organic material, mainly by settling of particles, would lead to rapid substrate exhaustion of the whole system.

The Red Sea shows several features which are 
unique among tropical oceans. It is landlocked with no river inflow and extremely scant rainfall restricted to the period between October and May. Due to its negative water balance salinity is high $(40.5 \%$ below $300 \mathrm{~m}$; Halim 1984). As a consequence, the subsurface Red Sea water is isothermal and warm (around $21.7^{\circ} \mathrm{C}$ ) to the bottom (Siedler 1969, Morcos 1970, Halim 1984). As nutrient concentrations are low, primary production has been considered to be less than $100 \mathrm{mg} \mathrm{C} \mathrm{m}^{-2} \mathrm{~d}^{-1}$ (Halim 1984, Thiel \& Weikert 1984). However, more recent evidence suggests that the true phytoplankton production is much higher ( $\left.>1 \mathrm{~g} \mathrm{C} \mathrm{m}^{-2} \mathrm{~d}^{-1}\right)$ because autotrophic picoplankton plays a major role and had escaped earlier measurements (Shaikh et al. 1986, Lenz et al. 1988, Moigis \& Weisse unpubl.). Although phytoplankton ecology and production (Shaikh et al. 1986) and zooplankton (Weikert 1982, Beckmann 1984 , Böttger 1987, Böttger-Schnack 1988) have been studied in the Red Sea, virtually nothing, to my knowledge, is known about bacterial and protozoan biomass, species composition and production in the Red Sea.

This paper presents results of growth and grazing experiments with pelagic bacteria and HNF using procaryotic and eucaryotic metabolic inhibitors obtained during a cruise of the German RV 'Meteor' through the Red Sea and the Indian Ocean in 1987. The experiments reported here were conducted in the central Red Sea and in the Gulf of Aden at the entrance to the Indian Ocean. The principal questions discussed in this paper are: (1) Do the microheterotrophs significantly contribute to overall secondary production? (2) Is there a close coupling between bacterial production and cropping, i.e. is the bacterial production largely controlled by grazing through HNF or other protozoans? (3) Is there any direct impact of the classic pelagic food web on the microbial loop? Evidence is provided that oscillations in bacterial abundances emerge from complex variations within the microbial loop.

\section{MATERIAL AND METHODS}

Experiments were carried out at 11 stations in the central Red Sea, from 3 to 24 February, and 6 stations in the Gulf of Aden, from 4 to 14 March 1987 (Fig. 1). All planktological data measured during the 'Meteor' cruise including the exact geographical positions of the stations investigated have been published by Lenz et al. (1988). Natural assemblages of pelagic bacteria and protozoans were taken with a 101 rosette water sampler from 9 standard depths: $0,5,10,20,30,40,50,75$, and $100 \mathrm{~m}$. Bacterial and HNF cell counts were made using epifluorescence microscopy and DAPI staining according to Porter \& Feig (1980). HNF were counted

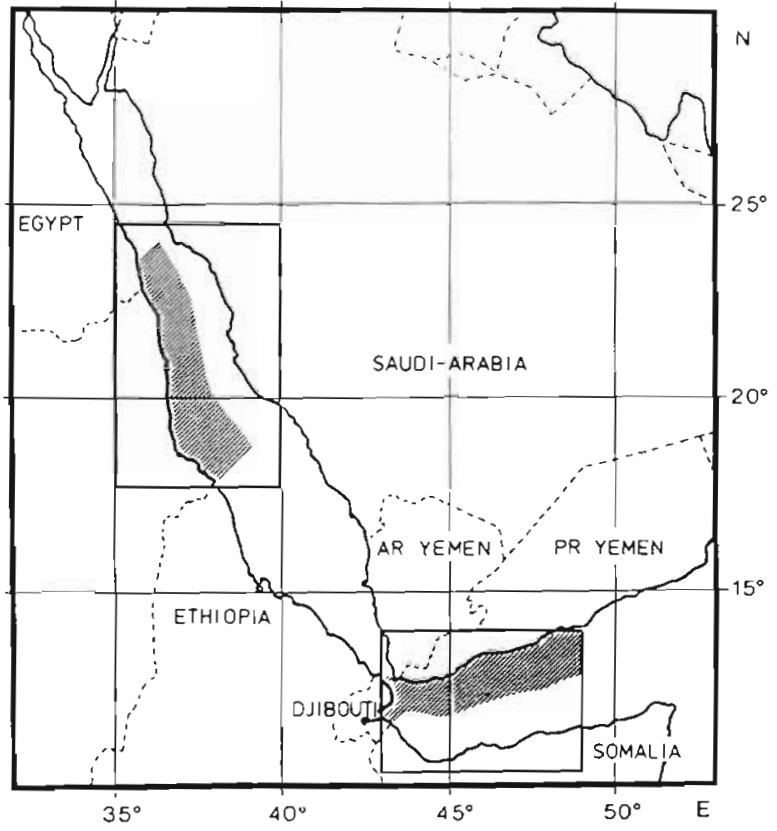

Fig. I Experimental areas (hatched) in the central Red Sea and Gulf of Aden

separately in 4 size classes: $<2 \mu \mathrm{m}, 2-5 \mu \mathrm{m}, 5-10 \mu \mathrm{m}$ $>10 \mu \mathrm{m}$. However, in this paper all flagellates will be lumped together and termed heterotrophic 'nano'flagellates for the sake of simplification. Details on the counting procedure and of the size distribution of HNF will be reported elsewhere (Weisse \& Gardinger unpubl.). The water from the different depths was mixed immediately after sampling and filtered through $200 \mu \mathrm{m}$ mesh gauze in order to exclude larger zooplankton such as copepods and coelenterates from experimental bottles. Experiments were conducted in $200 \mathrm{ml}$ glass bottles in the dark at the mean temperature of the upper $100 \mathrm{~m}$ of the water column $\left( \pm 1.5^{\circ} \mathrm{C}\right.$ ). Triplicate experiments were started within 10 to $20 \mathrm{~min}$ after sampling and incubated for $3 \mathrm{~h}$. Results reported are mean values.

Metabolic inhibitors which selectively affect either bacteria or eukaryotic grazers were used to estimate rates of bacterial growth and cropping. If cell growth or reproduction is prevented by prokaryote-specific inhibitors, the decrease in bacterial abundance is a direct measurement of grazing by eukaryotic nanoand microzooplankton. If grazing is eliminated by eukaryote-specific inhibitors, bacterial abundance increases according to continuous reproduction. A mixture of vancomycin (final concentration $200 \mathrm{mg} \mathrm{l}^{-1}$ ), an inhibitor of prokaryotic $70 \mathrm{~s}$ ribosome function, and penicillin/streptomycin (100 units $\mathrm{ml}^{-1 / 100} \mathrm{mg} \mathrm{l}^{-1}$ ), which inhibits cell wall synthesis (penicillin) and protein synthesis (streptomycin), was used to prevent bacterial growth. A mixture of cycloheximide (200 $\left.\mathrm{mg} \mathrm{l}^{-1}\right)$, 
an inhibitor of eukaryote 80 s function, and colchicin $\left(100 \mathrm{mg} \mathrm{l}^{-1}\right)$, which inhibits microtubulus formation, was used to eliminate eukaryote grazing. These antibiotics have been found by B. F. Sherr et al. (1986) to be the most specific agents out of 10 different metabolic inhibitors or mixtures of inhibitors used. In the Red Sea, I tested in a preliminary time-course experiment that the inhibition was effective during the $3 \mathrm{~h}$ of incubation (Fig. 2). Experimental bottles containing both pro- and

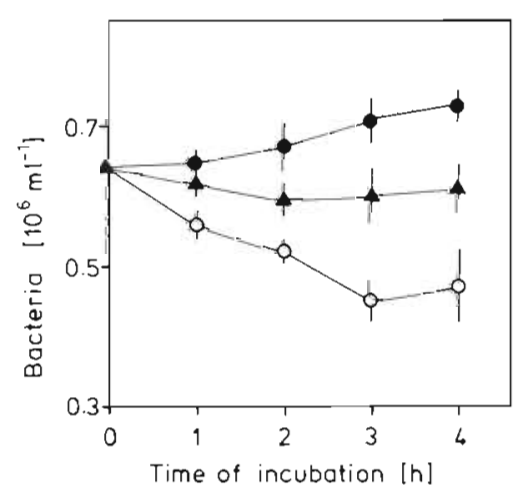

Fig. 2. Inhibitory effect of different inhibitors on epipelagic bacteria at $\operatorname{Stn} 66$. (•) Eukaryotic antibiotic mixture; (o) prokaryotic antibiotic mixture; (4) control with both mixtures added. Bars represent $\pm 1 \mathrm{SD}$

eukaryote inhibitors were used as controls for inhibitorinduced cell lysis. Changes in bacterial concentration in these controls were subtracted from the rate of decrease in the samples containing only prokaryote antibiotics. Cell lysis was generally of minor importance (below $10 \%$ of initial bacterial abundance during the $3 \mathrm{~h}$ of incubation). Untreated samples served as control for the efficacy of the inhibition technique applied. Change in bacterial concentrations in these controls yielded net population growth rates $\mu_{m}$. Theoretically, this change should equal the observed changes in eukaryotic minus prokaryotic inhibition treatments, $\mu_{c}$, as $\mu_{c}=k-g$ where ( $k$ is gross population growth rate, $g$ is grazing coefficient).

Growth and grazing rates were determined from the exponential model of population growth:

$$
N_{t}=N_{0} \quad e^{\mu t}
$$

where $N_{t}$ and $N_{0}=$ final and initial bacterial concentrations in the experimental bottles. During the $3 \mathrm{~h}$ of incubation there was no significant difference between exponential and linear population growth. However, as the population increase is exponential with longer incubation times (Weisse unpubl.), the exponential model was used to calculate daily bacterial production rates. For this purpose bacterial cell counts were converted to carbon assuming a bacterial biovolume of $0.05 \mu^{3} \mathrm{cell}^{-1}$ and a respective carbon content of $15 \mathrm{fg}$ C cell ${ }^{-1}$ (Simon \& Azam 1989).

Bacterial consumption rates (as bacteria ingested $\mathrm{HNF}^{-1} \mathrm{~h}^{-1}$ ) and clearance rates (as nl $\mathrm{HNF}^{-1} \mathrm{~h}^{-1}$ ) of HNF were calculated according to Davis \& Sieburth (1984).

\section{RESULTS}

The results obtained in routine experiments conducted in the central Red Sea and in the Gulf of Aden are reported in Figs, 3 to 6 . At the stations under discussion, surface water temperature varied between 22.9 and $27.1^{\circ} \mathrm{C}$. Surface salinity was higher in the central Red Sea $\left(38.40\right.$ to $\left.39.99 \times 10^{-3}\right)$ than in the Gulf
Fig. 3. Mean abundances ( 0 to $100 \mathrm{~m}$ ) of pelagic bacteria and heterotrophic nanoflagellates (HNF) in the central Red Sea and Gulf of Aden. Station numbers are indicated above

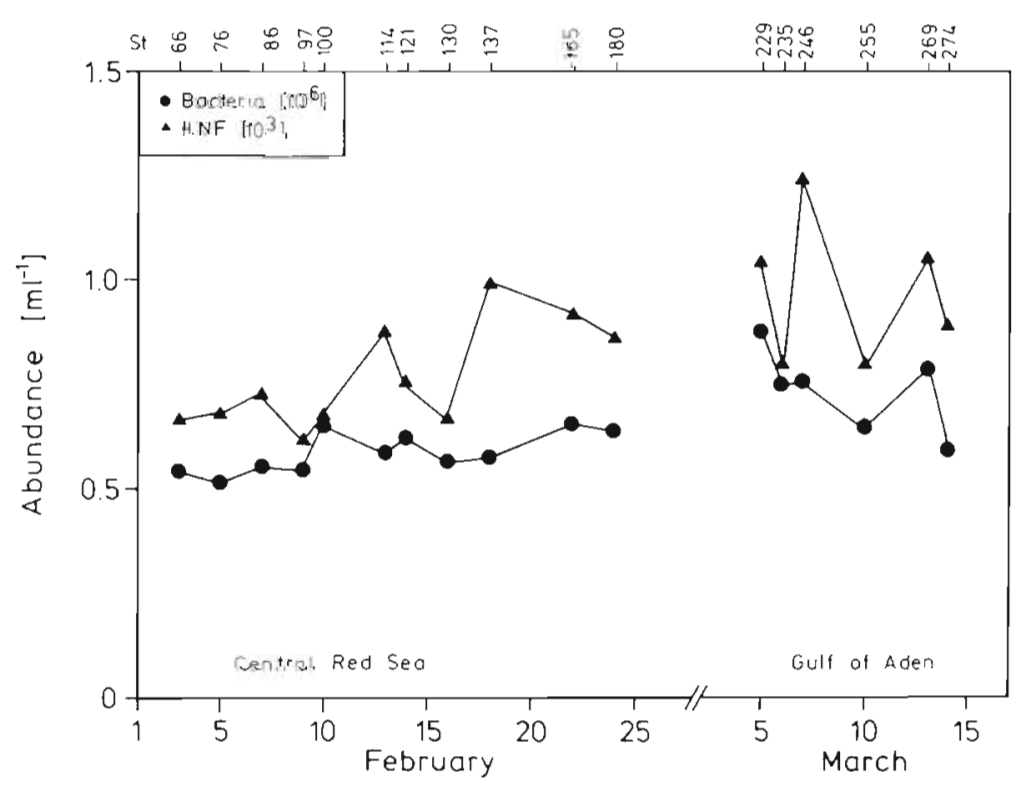




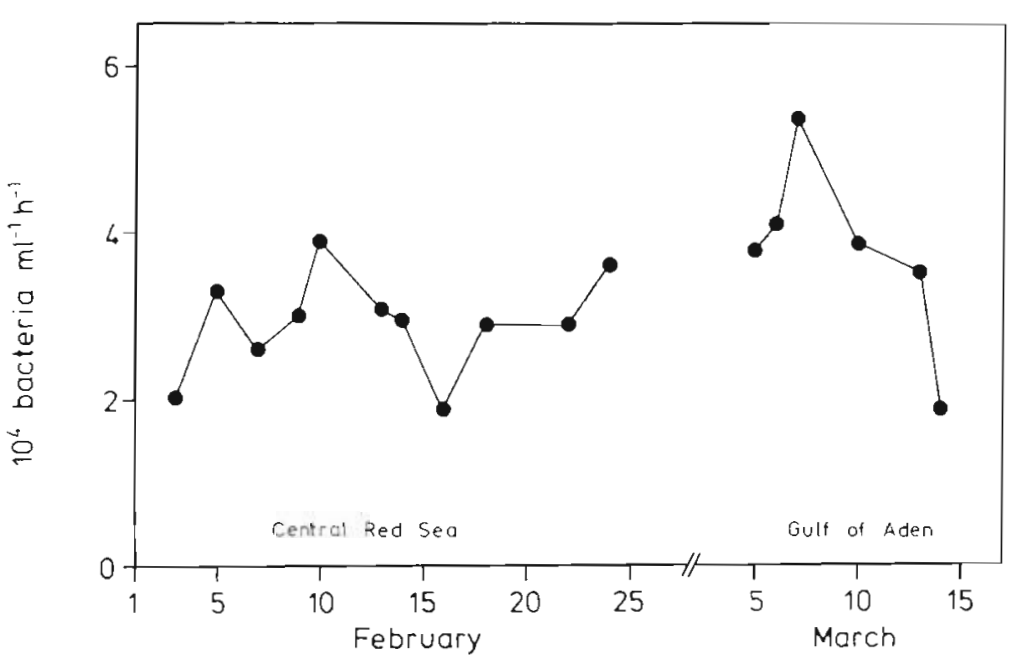

Fig. 4. Bacterial population grazing rates measured in the Red Sea and Gulf of Aden of Aden (36.19 to $\left.36.29 \times 10^{-3}\right)$. Inorganic nutrients were generally low in the upper $100 \mathrm{~m}$, and chlorophyll a concentration rarely exceeded $0.4 \mu \mathrm{g} \mathrm{l}^{-1}$. Nutrients, chlorophyll a content and primary production were all slightly higher in the Gulf of Aden than in the central Red Sea (for details see Lenz et al. 1988).

Although mean abundance were somewhat higher in the Gulf of Aden than in the central Red Sea, the variation in bacterial and HNF concentrations was comparatively small $\left(5.19\right.$ to $8.80 \times 10^{5}$ bacteria $\mathrm{ml}^{-1}$ and 6.15 to $12.40 \times 10^{2} \mathrm{HNF} \mathrm{ml}^{-1}$, respectively) at all stations investigated (Fig. 3). Bacterial population grazing rates calculated as the difference between final bacterial concentrations in experimental and control

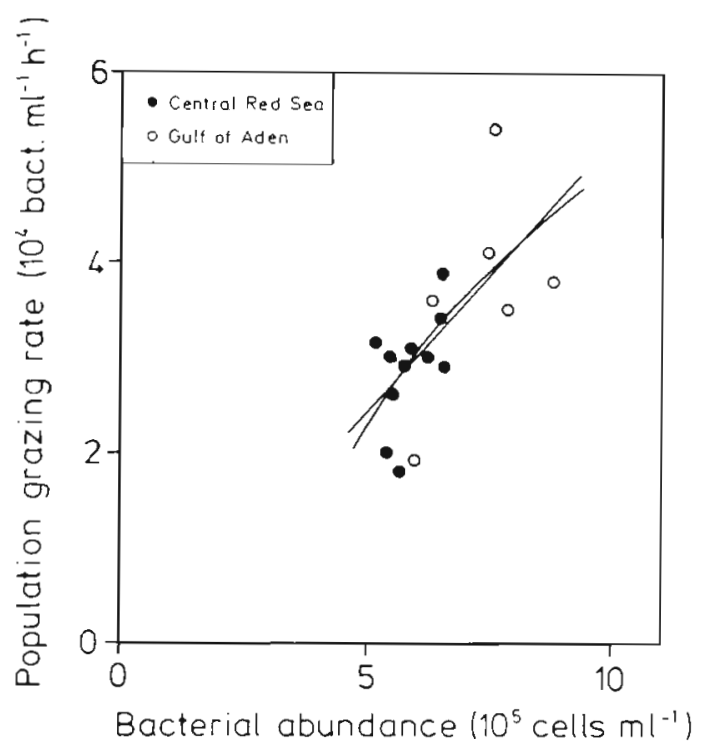

Fig. 5. Relationship between bacterial abundance and measured population grazing rate. Both linear and logarithmic (after log transformation of bacterial abundance) regression lines are indicated bottles varied by a factor of 3 (Fig. 4). Population grazing rates increased significantly $(r=0.635, \mathrm{n}=17$, $\alpha<0.01$ ) with increasing bacterial abundance (Fig. 5). There was no significant difference between linear and log-transformed linear regression of bacterial abundance versus population grazing rates. Grazing rates decreased sharply if bacterial concentrations fell below $0.6 \times 10^{6}$ cells $\mathrm{ml}^{-1}$.

The number of bacteria consumed per HNF and hour is computed on the assumption that $\mathrm{HNF}<20 \mu \mathrm{m}$ were the only bacterial consumers during the experiments (Fig. 6). Thus, the consumption rates calculated have to be regarded as maximum values and true ingestion rates might be lower for reasons discussed further below. The same holds true for the clearance rates which are also shown in Fig. 6.

Loss rates of bacterial production by protozoan grazing as obtained in the bottles with prokaryote-specific inhibitors were compared to bacterial growth rates measured in bottles with eukaryote-specific inhibitors (Table 1). In 10 out of 14 experimental series there was a close agreement between the net growth rate measured in untreated controls $\left(\mu_{m}\right)$ and the net growth rate calculated as the difference between eukaryotic and prokaryotic inhibitor experiments $\left(\mu_{c}\right)$. Thus provides strong evidence for the reliability of the inhibitory technique applied. Net growth rates of pelagic bacteria and of HNF appeared to be inversely related to each other (Fig. 7). The time lag between the most negative bacterial net growth rate measured in the first experiment (3 February) and the most positive value obtained at $\operatorname{Stn} 114$ (13 February) was $10 \mathrm{~d}$. Thereafter, bacterial net growth rates decreased again. A similar pattern of combined changes between bacterial and HNF net growth rates was observed in the Gulf of Aden, although the investigation period was too short to reveal one complete cycle. Bacterial net growth rates 
Fig. 6. Ingestion rate (left $Y$-axis) and clearance rate (right $\mathrm{Y}$-axis) of heterotrophic nanoflagellates during the experiments

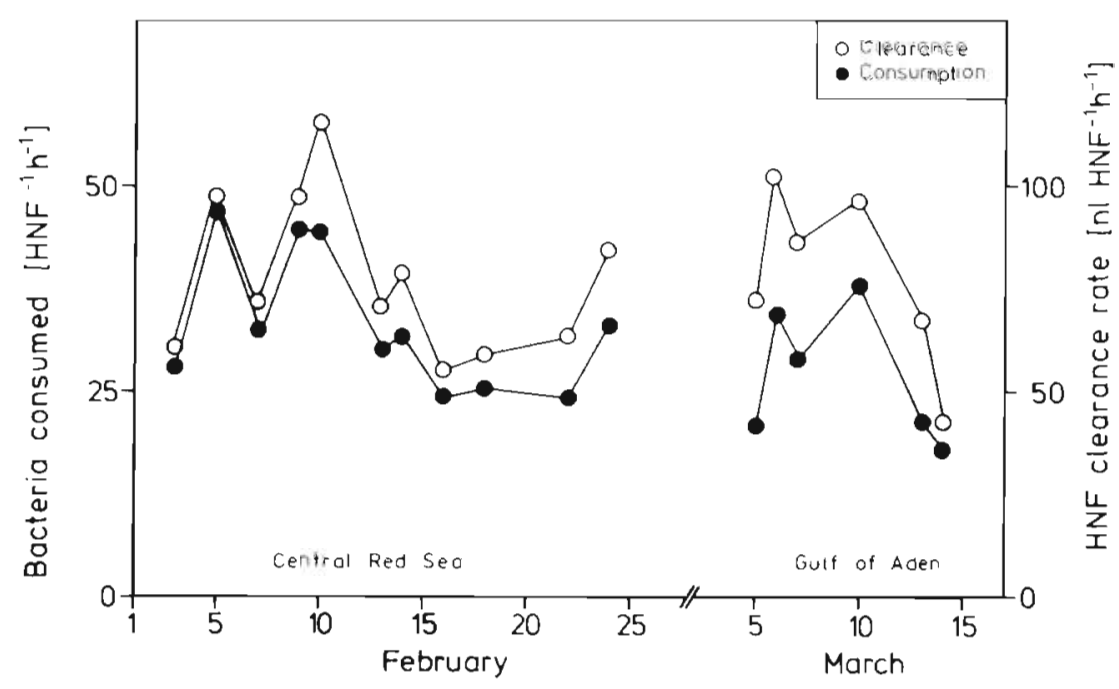

Table 1 Growth characteristics of pelagic bacteria during the experiments. $k$ : gross growth rate; $g$ : grazing loss rate; $\mu_{c}$ : net growth rate calculated as $\mu_{c}=k-g_{i} \mu_{m}$ : net growth rate measured in untreated control bottles; $G$ : doubling time

\begin{tabular}{|c|c|c|c|c|c|c|}
\hline $\begin{array}{l}\text { Date } \\
(1987)\end{array}$ & Station & $k\left(h^{-1}\right)$ & $g\left(\mathrm{~h}^{-1}\right)$ & $\mu_{c}\left(\mathrm{~h}^{-1}\right)$ & $\mu_{m}\left(h^{-1}\right)$ & $G(h)$ \\
\hline \multicolumn{7}{|c|}{ Central Red Sea } \\
\hline 3 Feb & 66 & 0.033 & 0.108 & -0.075 & - & 21.3 \\
\hline 5 Feb & 76 & 0.047 & 0.079 & -0.032 & - & 14.8 \\
\hline 7 Feb & 86 & 0.028 & 0.033 & -0.005 & +0.055 & 24.9 \\
\hline $9 \mathrm{Feb}$ & 97 & 0.043 & 0.095 & -0.053 & -0.066 & 16.3 \\
\hline $13 \mathrm{Feb}$ & 114 & 0.097 & 0.010 & +0.087 & +0.102 & 7.2 \\
\hline $14 \mathrm{Feb}$ & 1.21 & 0.045 & 0.029 & +0.016 & +0.030 & 15.5 \\
\hline $16 \mathrm{Feb}$ & 130 & 0.091 & 0.030 & +0.061 & +0.063 & 7.6 \\
\hline 18 Feb & 137 & 0.096 & 0.038 & +0.058 & +0.061 & 7.2 \\
\hline $22 \mathrm{Feb}$ & 165 & 0.068 & 0.042 & +0.026 & +0.025 & 10.2 \\
\hline $24 \mathrm{Feb}$ & 180 & 0.087 & 0.069 & +0.018 & +0.015 & 8.0 \\
\hline \multicolumn{2}{|c|}{$\begin{array}{l}\text { Mean } \\
\pm S D\end{array}$} & $\begin{array}{r}0.064 \\
+0.027\end{array}$ & $\begin{array}{r}0.055 \\
\pm 0.031\end{array}$ & $\begin{array}{l}+0.008 \\
\pm 0.052\end{array}$ & - & $\begin{array}{r}13.3 \\
\pm \quad 6.3\end{array}$ \\
\hline \multicolumn{7}{|c|}{ Gulf of Aden } \\
\hline 5 Маг & 229 & 0.038 & 0.043 & -0.005 & +0.024 & 18.2 \\
\hline 6 Mar & 235 & 0.022 & 0.060 & -0.038 & -0.057 & 31.5 \\
\hline 7 Mar & 246 & 0.021 & 0.085 & -0.064 & -0.020 & 33.0 \\
\hline $10 \mathrm{Mar}$ & 255 & 0.014 & 0.069 & -0.055 & -0.062 & 49.7 \\
\hline $13 \mathrm{Mar}$ & 269 & 0.028 & 0.052 & -0.024 & -0.073 & 24.8 \\
\hline $14 \mathrm{Mar}$ & 274 & 0.050 & 0.033 & +0.017 & +0.029 & 13.9 \\
\hline \multicolumn{2}{|c|}{$\begin{array}{l}\text { Mean } \\
\pm \mathrm{SD}\end{array}$} & $\begin{array}{r}0.029 \\
\pm \quad 0.013\end{array}$ & $\begin{array}{r}0.057 \\
\pm 0.018\end{array}$ & $\begin{array}{r}-0.028 \\
\pm 0.031\end{array}$ & $\begin{array}{l}-0.027 \\
\pm 0.045\end{array}$ & $\begin{array}{r}28.5 \\
+12.7\end{array}$ \\
\hline
\end{tabular}

and HNF net growth rates of the central Red Sea stations (Fig. 8) were significantly correlated $(\mathrm{n}=8, \mathrm{r}=$ $-0.886, \alpha<0.01$ ) with least squares linear regression equation of the form:

$$
\mu_{\text {Bact. }}\left(\mathrm{h}^{-1}\right)=0.013-0.728 \mu_{\mathrm{HNF}}\left(\mathrm{h}^{-1}\right)
$$

Thus, under balanced conditions when HNF growth is zero bacteria would grow slowly $\left(\mu_{\text {Bact. }}=0.013 \mathrm{~h}^{-1}\right)$ at a rate which amounts to $24 \%$ of the measured mean gross growth rate $\left(k=0.064 \mathrm{~h}^{-1}\right)$. This means that under balanced conditions $76 \%$ of the bacterial production was cropped by HNF grazing during the day. The residue of $24 \%$ is the extent to which HNF ingestion rates presented in Fig. 6 might have been overestimated. Therefore, the average ingestion rate would be about 29 bacteria $\mathrm{HNF}^{-1} \mathrm{~h}^{-1}$.

In both investigation areas maximum gross growth rates coincided with minimum grazing rates and vice versa. Least squares linear regression revealed a negative relationship which is, however, statistically insig- 


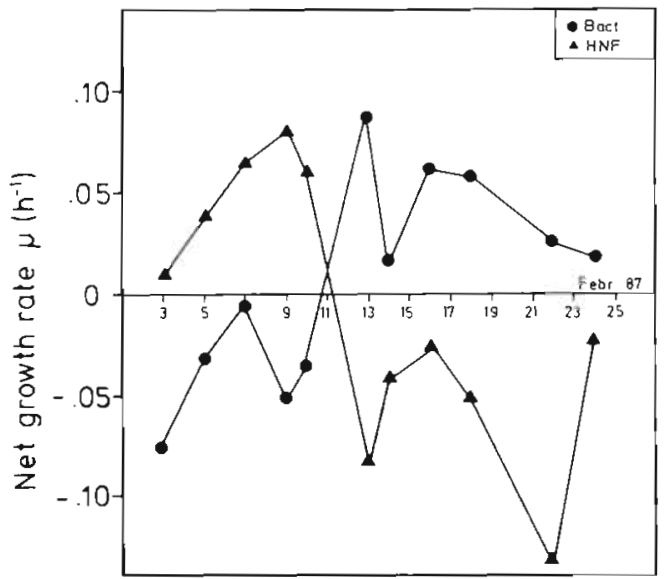

Fig. 7 Inverse relationship between net growth rates $\mu$ of pelagic bacteria and heterotrophic nanoflagellates in the central Red Sea

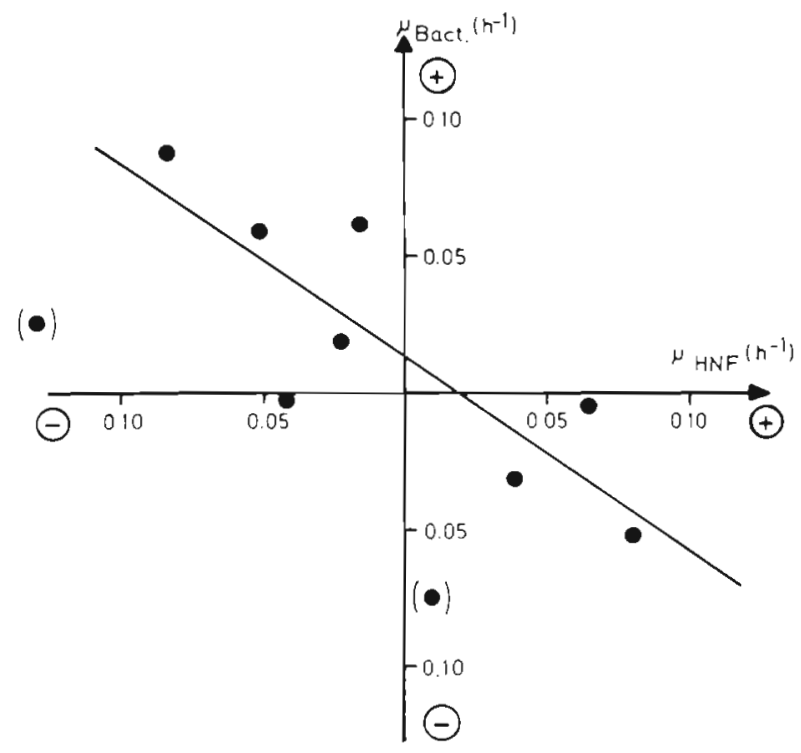

Fig. 8. Least squares linear regression between net growth rates of bacteria $\left(\mu_{\text {kact }}\right)$ and heterotrophic nanoflagellates $\left(\mu_{\mathrm{HNF}}\right)$ in the central Red Sea

nificant ( $\mathrm{n}=16, \mathrm{r}=-0.476, \alpha<0.1)$. Therefore, the regression equation is not given here. Yet it is mentioned because the resulting equation would allow to calculate bacterial gross growth rates if total grazing pressure within the microbial loop (including grazers others as HNF) were zero. This might be a useful tool for future studies in order to evaluate the percentage of HNF grazing among the total grazing pressure on bacteria within the microbial loop.

It is obvious from the negative net growth rates that occurred (Figs. 7 and 8) that HNF were preyed upon by nano- or microplankton sized grazers $(<200 \mu \mathrm{m})$ since larger zooplankton was removed from the experiments by prefiltration through $200 \mu \mathrm{m}$ mesh gauze. Although I do not have direct evidence, it is likely that ciliates and heterotrophic dinoflagellates, which were relatively abundant during the investigation period (R. Gradinger unpubl.), were the most important grazers of HNF.

In order to estimate daily bacterial production, diurnal variations in growth and grazing rates of pelagic bacteria have to be taken into consideration. Grazing experiments conducted at Stns 100 and 180 at various times during day and night indicate a substantial reduction of grazing activity during night (Fig. 9). Diurnal changes in bacterial growth rates were only measured at Stn 180. During day and during the first half of night growth rates were rather constant $(k=0.081 \pm$ $\left.0.020 h^{-1}, n=4\right)$. In the second half of night, however, no growth at all occurred during the experiments. Considering these results and assuming $12 \mathrm{~h}$ daylength, daily bacterial production and loss rates due to grazing were calculated correcting the values measured in the routine experiments as follows:

$$
k\left(\mathrm{~d}^{-1}\right)=k\left(\mathrm{~h}^{-1}\right) \times 24 \times 0.9
$$

and

$$
g\left(\mathrm{~d}^{-1}\right)=g\left(\mathrm{~h}^{-1}\right) \times 12+0.5 g \times 12
$$

Bacterial production rates thus calculated are reported in Table 2. Gross bacterial production integrated over the upper $100 \mathrm{~m}$ of the water column amounted to 0.50 to $1.86 \mathrm{~g} \mathrm{C} \mathrm{m}^{-2} \mathrm{~d}^{-1}$.
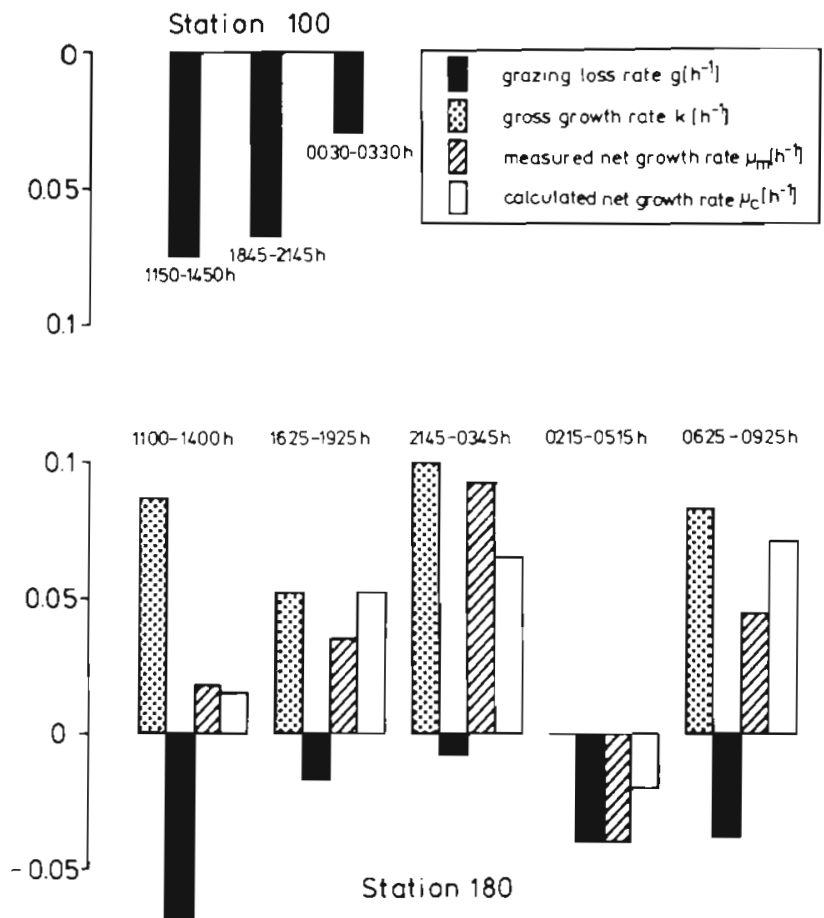

Fig, 9. Diurnal vanation of bacterial growth and grazing loss rates at 2 stations in the Red Sea. Growth rates were only measured at Stn 180 (lower panel) 
Table 2. Daily bacterial production and grazing loss rates $\left(\mathrm{g} \mathrm{C} \mathrm{m} \mathrm{m}^{-2} \mathrm{~d}^{-1}\right)$. Measured growth $(k)$ and grazing $(g)$ coefficients were corrected according to Eqs. (3) and (4), respectively (see text)

\begin{tabular}{|c|c|c|c|c|}
\hline Station & $k_{\text {cor }}\left(\mathbf{d}^{-1}\right)$ & $g_{\operatorname{cor}}\left(\mathrm{d}^{-1}\right)$ & Bact. prod. & Grazing loss \\
\hline \multicolumn{5}{|c|}{ Central Red Sea } \\
\hline 66 & 0.71 & 1.94 & 0.58 & 1.58 \\
\hline 76 & 1.01 & 1.42 & 0.79 & 1.11 \\
\hline 86 & 0.60 & 0.59 & 0.50 & 0.49 \\
\hline 97 & 0.93 & 1.71 & 0.76 & 1.40 \\
\hline 114 & 2.10 & 0.18 & 1.86 & 0.16 \\
\hline 121 & 0.97 & 0.52 & 0.90 & 0.48 \\
\hline 130 & 1.97 & 0.54 & 1.68 & 0.46 \\
\hline 137 & 2.07 & 0.68 & 1.79 & 0.59 \\
\hline 165 & 1.47 & 0.76 & 1.45 & 0.75 \\
\hline 180 & 1.88 & 1.24 & 1.80 & 1.19 \\
\hline Mean & 1.37 & 0.96 & 1.21 & 0.82 \\
\hline$\pm \mathrm{SD}$ & \pm 0.59 & \pm 0.58 & \pm 0.55 & \pm 0.47 \\
\hline \multicolumn{5}{|c|}{ Gulf of Aden } \\
\hline 229 & 0.82 & 0.77 & 1.08 & 1.02 \\
\hline 235 & 0.48 & 1.08 & 0.54 & 1.21 \\
\hline 246 & 0.45 & 1.53 & 0.57 & 1.73 \\
\hline 255 & 0.30 & 1.24 & 0.29 & 1.20 \\
\hline 269 & 0.60 & 0.94 & 0.71 & 1.11 \\
\hline 274 & 1.08 & 0.59 & 0.96 & 0.52 \\
\hline Mean & 0.62 & 1.03 & 0.69 & 1.13 \\
\hline$\pm \mathrm{SD}$ & \pm 0.28 & \pm 0.34 & \pm 0.29 & \pm 0.39 \\
\hline
\end{tabular}

\section{DISCUSSION}

This paper presents the first report on population dynamics of pelagic microorganisms belonging to the microbial loop in the Red Sea. In relation to the overall energy flow the microbial loop is overwhelmingly important in the Red Sea. The picoplankton size fraction $<2 \mu \mathrm{m}$ comprised $69 \%$ of the chlorophyll a concentration and $77 \%$ of the primary production (T. Pillen \& A. Moigis, cited in Lenz et al. 1988). Including bacteria, over $90 \%$ of the planktonic production occurs within the microbial loop. As there is no important direct impact of the larger zooplankters on the pelagic microorganisms except for the cropping of larger protozoans, the energy channelled through the microbial loop is mainly produced and consumed within organisms smaller than $20 \mu \mathrm{m}$ in size.

Growth dynamics of pelagic bacteria and HNF presented here were analysed with selective metabolic inhibitors. The use of metabolic inhibitors to estimate bacterial grazing rates was first proposed by Newell et al. (1983) and since then has been applied with several modifications (Fuhrman \& McManus 1984, Campbell \& Carpenter 1986, Sanders \& Porter 1986, B. F. Sherr et al. 1986). At present there is no accepted standard method by which to judge the accuracy of the results obtained from inhibitor experiments (B. F. Sherr et al. 1986). If bacterial gross growth rates $(k)$ in eucaryote inhibitor experiments and bacterial grazing rates $(g)$ in procaryote inhibitor experiments are measured accurately, the net growth rate $\mu_{c}$ can be calculated as $\mu_{c}=k-g$. The result should be the same as the net change of bacterial concentrations occurring in untreated controls $\left(\mu_{m}\right)$, and thus provides a tool to estimate the accuracy of the experimental approach used. As in the experiments under discussion the agreement between results calculated from inhibitor treatments and measured in control samples in general was close, the assumptions commonly involved in inhibitor experiments (B. F. Sherr et al. 1986) have obviously been fullfilled. Although artifacts such as containment effects inherent in enclosure experiments cannot be completely excluded from this study, much indirect evidence suggests that artifacts were of minor importance. For instance, the observed inverse relationship between bacterial and HNF net growth rates (Fig. 7) can hardly be explained by artifacts. The same holds true for the increase in bacterial population grazing rate with increasing bacterial abundance (Fig. 5) and for the diurnal shifts in bacterial grazing rates measured at Stns 100 and 180 (Fig. 9).

The initial assumption that HNF are the major bacterial grazers could be proved by the significant negative relationship between bacterial and HNF net growth rates (Eq. 2). The fact that the resulting regression line meets the ordinate close to the origin (Fig. 8) clearly demonstrates the importance of HNF in controlling bacterial population growth. Net growth of pelagic bacteria occurred only when the standing stack of HNF grew very slowly or decreased. The residue of up to $24 \%$ of bacterial grazing which cannot be addressed to HNF might be cropped by other protozoan bacterivores such as ciliates and heterotrophic dinoflagellates which were not included in this study. The conclusion that larger protozoans are only of minor importance as bacterial predators is in agreement with previous observations made by other investigators in different oceanic areas (Azam et al. 1983, Davis \& Sieburth 1984, Wright \& Coffin 1984, E. B. Sherr et al. 1986, Hagström et al. 1988). As the small HNF of the Red Sea did not contain autofluorescent cells in their food vacuoles and other particles in the size range below $2 \mu \mathrm{m}$ did not occur, bacteria must have been the major particulate diet of HNF. Dissolved high molecular weight polysaccharides eventually could supply HNF with another food source of unknown importance (Sherr 1988). Thus, although I cannot rule out methodological problems involved in the experimental approach used, the consistent results indicate that bacterial and HNF growth and grazing rates were measured accurately and are valid estimates of natural bacterial growth and cropping. Accordingly, bacterial and HNF growth and graz- 
ing rates are in good agreement with previous results obtained in similar studies (Davis \& Sieburth 1984, Landry et al. 1984, B. F. Sherr et al. 1986, Weisse 1989).

At bacterial concentrations of $5 \times 10^{5}$ cells $\mathrm{ml}^{-1}$ in the Sargasso Sea, Davis \& Sieburth (1984) measured an average population grazing rate of $2.5 \times 10^{4}$ bacteria $\mathrm{ml}^{-1} \mathrm{~h}^{-1}$. Off Hawail, population grazing rate varied from 1.5 to $3.4 \times 10^{4}$ bacteria $\mathrm{ml}^{-1} \mathrm{~h}^{-1}$ (Landry et al. 1984). In oligotrophic Mediterranean waters, bacterial consumption amounted to $2.6 \times 10^{4}$ bacteria $\mathrm{ml}^{-1} \mathrm{~h}^{-1}$ (Wikner et al. 1986, Hagström et al. 1988). These values are close to my results from the central Red Sea (average population grazing rate $2.9 \times 10^{4}$ bacteria $\mathrm{ml}^{-1} \mathrm{~h}^{-1}$ ) and from the Gulf of Aden (mean value $3.75 \times 10^{4}$ bacteria $\mathrm{ml}^{-1} \mathrm{~h}^{-1}$ ). Considerable higher population grazing rates were found in eutrophic coastal waters (reviewed by B. F. Sherr et al. 1986). In the present study, HNF grazing rates corresponded to consumption rates of 21 to 58 bacteria $H N^{-1} \mathrm{~h}^{-1}$. Clearances varied from 36 to $94 \mathrm{nl} \mathrm{HNF}^{-1} \mathrm{~h}^{-1}$. These rates are within the range of values found by other investigators in various marine environments (for review see B. F. Sherr et al. 1986). However, volume-specific clearance rates reported in the present study are considerably higher than maximum specific clearance rates measured by Fenchel (1982) with cultured flagellates. Fenchel (1987) argued that volume-specific clearance rates of suspension feeding protozoans usually do not exceed $10^{5}$ body volumes per $h$. Nevertheless, this does not necessarily hold for central oligotrophic parts of the oceans, because: (1) In contrast to consumption rates, clearances decrease with increasing prey density since clearance is consumption divided by bacterial concentration (Davis \& Sieburth 1984). These authors found decreasing clearance rates with increasing prey density in Narragansett Bay and in the Sargasso Sea. I also measured higher average clearance rates in the central Red Sea at lower bacterial concentrations than in the Gulf of Aden. (2) Specific clearance rates are inversely related to cell size (Fenchel 1982), and average cell size of protozoans in oligotrophic areas is small. (3) Water temperature in oligotrophic central parts of the oceans is usually higher than in temperate or boreal coastal zones where the majority of comparable studies originate. In the present investigation, surface water temperature varied from 22.9 to $25.9^{\circ} \mathrm{C}$. Since the $Q_{10}$ value of physiological rate constants of protozoans is within 2 to 3 (Fenchel 1987), the results obtained in the Red Sea should be distinctly higher than clearance rates measured at $20^{\circ} \mathrm{C}$ (Fenchel 1982) or at lower temperatures. In summary, high clearance rates reported here seem to be reliable and are in good agreement with values found by Davis \& Sieburth (1984) in the Sargasso Sea at comparable bacterial concentrations. For example, for a small Oikomonas 2 to $3 \mu \mathrm{m}$ in diameter they measured clearance rate of 65 $\mathrm{nl}$ individual $\mathrm{l}^{-1} \mathrm{~h}^{-1}$ at $21^{\circ} \mathrm{C}$. This is equivalent to 5 to 10 $\times 10^{6}$ body volumes of water cleared per $\mathrm{h}$ and flagellate. Average consumption and clearance rates in oceanic waters of the Sargasso Sea were 50 bacteria $\mathrm{HNF}^{-1} \mathrm{~h}^{-1}$ and $100 \mathrm{nl} \mathrm{HNF}{ }^{-1} \mathrm{~h}^{-1}$, respectively.

In order to compare bacterial production and loss rates with phytoplankton primary production and zooplankton secondary production on a daily basis, possible diurnal rhythms which are known for many physiological rates must be taken into consideration. Lower bacterial growth rates during night-time have been demonstrated by several investigators and explained by reduced substrate supply at night due to a tight coupling between phytoplankton exsudate release and bacterial production (Hagström \& Larsson 1984, Fuhrman et al. 1985 and references therein). Experiments conducted at Stns 100 and 180 suggest a considerable drop of bacterial grazing and moderately decreased bacterial growth rates at night. Fuhrman et al. (1985) also reported some evidence for reduced bacterial ingestion rates by flagellates during night. Wikner et al. (1987) found a strong diel variation in the activity of bacterivorous small HNF in different marine areas. HNF grazing activity was highest at noon and ceased in early morning hours, when the flagellates divided. Therefore, the cropping of bacterial production by protozoa might be less than derived from the comparison of measured growth and grazing coefficients of pelagic bacteria because the routine experiments were run in late morning hours when grazing rates were high. Yet, even assuming a 50\% reduction of grazing rates at night, two-thirds of bacterial production was removed by grazing within the microbial loop in the central Red Sea. The assumed $50 \%$ decrease of grazing during night-time would reduce daily grazing rates by about $25 \%$ (daylength $12 \mathrm{~h}$ ). This is the maximum error involved in Eq. (4). In the Strait of Bab el Mandeb and the Gulf of Aden grazing loss was even higher than bacterial production, because during the period of investigation bacterial growth was relatively low and grazing comparatively high. As measured net growth rates tended to increase in the last 3 experiments it is likely that production rates would have surpassed grazing losses if the experimental period would have been prolonged. Well-pronounced variations in net growth rates of bacteria and HNF have been observed in both experimental areas. Thus, although there was a general positive relationship between bacterial concentration and population grazing rate (Fig. 4) averaged over the investigation area as also found in other areas (Weisse unpubl.) the close coupling between production and loss rates induced considerable daily variation. These findings evidently need further experimental justification. 
If the described interplay between growth and grazing is a general feature of aquatic microorganism communities under balanced conditions, which are often met not only in the tropical ocean, this has far-reaching consequences. For instance, if we consider only the results obtained at Stns 114 to 180 between 13 and 24 February we would conclude that only $45 \%$ of the bacterial production would be removed by grazing within the microbial loop. Consequently, one would assume that grazing by larger zooplankton or other loss factors such as autolytic cell disintegration or sedimentation must be more important in controlling bacterial production in the central Red Sea. However, averaged over the entire investigation period bacterial production is largely controlled by grazing within the microbial loop.

All these combined temporal variations point to a close coupling between the different components of the microbial loop in the Red Sea. Not only bacterial production but also bacterial gross growth rates are largely controlled by grazing pressure. Bacteria obviously react with increasing net growth to decreasing grazing inpact. The production of heterotrophic nanoflagellates, the major bacterial predators, is mainly controlled by larger protozoa within the microbial loop. Indirectly, bacteria profit by larger protozoan feeding on HNF. The bacterial production is mainly channeled through a 2-step protozoan food chain, and control is performed from top to bottom.

Estimates of bacterial production presented here appear to be high relative to phytoplankton primary production. In part this may be due to the relatively high bacterial carbon conversion factor (about $300 \mathrm{fg} \mathrm{C}$ $\mathrm{um}^{-3}$ ) assumed here. Furthermore, if a large percentage of the bacterial production is immediately removed by grazing, the exponential model of population growth used here would overestimate the true bacterial production. However, the balance between bacterial production and cropping was observed only if averaged over a longer time period ( $2 \mathrm{wk}$ ) and a larger area of investigation. Yet, if respiration losses are included bacterial production would be at least as high as particulate primary production in the Red Sea. This seeming paradox can easily be solved, since it has been demonstrated recently that summed secondary production (including bacterial production) may exceed primary production, especially in retentive systems such as the open oligotrophic ocean (Scavia 1988, Strayer 1988). However, there is evidence that the common ${ }^{14} \mathrm{C}$ technique greatly underestimated the true primary production in the Red Sea. With the routine ${ }^{14} \mathrm{C}$ technique particulate primary production rates between 0.099 and $0.659 \mathrm{~g} \mathrm{C} \mathrm{m}^{-2} \mathrm{~d}^{-1}$ were measured during the 'Meteor' cruise (A. Moigis, data reported by Lenz et al. 1988). The amount of dissolved primary production remains unknown. Using a dilution technique according to Landry \& Hasset (1982) Moigis measured phytoplankton gross growth rates up to $0.39 \mathrm{~h}^{-1}$. The average growth rate of $0.18 \mathrm{~h}^{-1}$ would be equivalent to a primary production rate of $2.1 \mathrm{~g} \mathrm{C} \mathrm{m}^{-2} \mathrm{~d}^{-1}$. Independently measured high planktonic respiration (G. Schneider, cited in Lenz et al. 1988) and grazing rates among autotrophic picoplankton (T. Weisse unpubl.) also require a primary production rate which is nearer 2 than $0.25 \mathrm{~g} \mathrm{C} \mathrm{m}^{-2} \mathrm{~d}^{-1}$ (the measured average of the in situ ${ }^{14} \mathrm{C}$ incubations). Considering these high production estimates and the uncertainties involved in the calculations the bacterial production derived from the inhibition experiments appears to be reliable.

The microbial loop in the Red Sea emerges as a dynamic and to a large extent self-regulating subsystem of the pelagic ecosystem. Although only a minor part of the microbial production is used by larger organisms, it should not be termed a 'sink' in the pelagic energy transfer unless we know whether the classic pelagic food web would be substantially altered by a complete removal of the microbial loop. As this question might remain principally academic I suggest avoiding the terms 'sink' and 'link', and in future studies properly analyzing the coupling between the microbial loop and the classic pelagic food web.

Acknowledgements. The skilful technical assistance of the crew of RV 'Meteor' and the efforts of the cruise leader, $H$. Thiel, are gratefully acknowledged. I thank my colleagues from the Institut für Meereskunde, Kiel, J. Lenz and his coworkers, for collaboration and support of my work. M. Simon, M. M. Tilzer and 3 anonymous reviewer contributed substantially to the improvement of the manuscript. This work was financially supported by the Stiftung Volkswagenwerk and by a grant from the Deutsche Forschungsgemeinschaft to J. Lenz (Le/232-16).

\section{LITERATURE CITED}

Azam, F., Fenchel, T., Field, J. G., Gray, J. S., Meyer-Reil, L. A., Thingstad, F. (1983). The ecological role of watercolumn microbes in the sea. Mar. Ecol. Prog. Ser. 10: $257-263$

Beckmann, W. (1984). Mesozooplankton distribution on a transect from the Gulf of Aden to the central Red Sea during the winter monsoon. Oceanologica Acta 7: 87-102

Böttger, R. (1987). The vertical distribution of micro- and small mesozooplankton in the central Red Sea. Biol. Oceanogr. 4: $383-402$

Böttger-Schnack, R. (1988). Observations on the taxonomic composition and vertical distribution of cyclopoid copepods in the central Red Sea. Hydrobiologia 167/168: 311-318

Campbell, L., Carpenter, E. J. (1986). Estimating the grazing pressure of heterotrophic nanoplankton on Synechococcus spp. using the sea water dilution and selective inhibitor techniques. Mar. Ecol. Prog. Ser. 33: 121-129

Cole, J. J., Findlay, S., Pace, M. L. (1988). Bacterial production 
in fresh and saltwater ecosystems: a cross-system overview. Mar. Ecol. Prog. Ser. 43: 1-10

Davis, P. G., Sieburth, J. McN. (1984). Estuarine and oceanic microflagellate predation of actively growing bacteria estimation by frequency of dividing-divided bacteria. Mar Ecol. Prog. Ser. 19: 237-246

Dugdale, R. C., Goering, J. J. (1967). Uptake of new and regenerated forms of nitrogen in primary productivity. Limnol. Oceanogr. 12: 169-206

Eppley, R. W. (1981). Autotrophic production of particulate matter. In: Longhurst, A. R. (ed.) Analysis of marine ecosystems. Academic Press, London, p. 343-361

Fenchel, T. (1982). Ecology of heterotrophic microflagellates. II Bioenergetics and growth. Mar. Ecol. Prog. Ser. 8: 225-231

Fenchel, T. (1987). Ecology of Protozoa. Science Tech Publ., Madison, WI

Fuhrman, J. A., Eppley, R. W., Hagström, A., Azam, F. (1985) Diel variations in bacterioplankton, phytoplankton, and related parameters in the Southern California Bight. Mar. Ecol. Prog. Ser. 27: 9-20

Fuhrman, J. A., McManus, G. B. (1984). Do bacteria-sized marine eucaryotes consume significant bacterial production? Science 224: 1257-1260

Hagström, A., Azam, F., Andersson, A., Wikner, J., Rassoulzadegan, F. (1988). Microbial loop in an oligotrophic pelagic marine ecosystem: possible roles of cyanobacteria and nanoflagellates in the organic fluxes. Mar. Ecol. Prog. Ser, 49: $171-178$

Hagström, A., Larsson, U. (1984). Diel and seasonal variation in growth rates of pelagic bacteria. In: Hobbie, J. E., Williams, P. J. leB. (eds.) Heterotrophic activity in the sea. Plenum Press, New York, p. 249-262

Halim, Y. (1984). Plankton of the Red Sea and the Arabian Gulf. Deep Sea Res. 31: 969-982

Lampert, W (1978). Release of dissolved organic carbon by grazing zooplankton. Limnol. Oceanogr. 23: 831-834

Landry, M. R. Haas, L. W., Fagerness, V L. (1984). Dynamics of microbial plankton communities: experiments in Kaneohe Bay, Hawaii. Mar. Ecol. Prog. Ser. 16: 127-133

Lenz, J., Schneider, G., El Hag, A. G. D., Gradinger, R., Fritsche, P., Moigis, A., Pillen, T., Rolke, M., Weisse, T (1988). Planktological data from the central Red Sea and the Gulf of Aden. Ber. Inst. Meeresk. Univ. Kiel 180: 1-200

Morcos, S. A. (1970). Physical and chemical oceanography of the Red Sea. Oceanogr. Mar. Biol. A. Rev. 8: 73-202

Newell, S. Y., Sherr, B. F., Sherr, E. B., Fallon, R. D. (1983). Bacterial response to presence of eukaryote inhibitors in water from a coastal marine environment. Mar. environ Res. 10: 147-157

Poisson, A., Morcos, S., Souvermezoglou, E., Papaud, A., Ivanoff, A. (1984). Some aspects of biogeochemical cycles in the Red Sea with special reference to new observations made in summer 1982. Deep Sea Res. 31: 707-718

Porter, K. G., Feig, Y S. (1980). The use of DAPI for identifying and counting aquatic microflora. Limnol. Oceanogr. 25 943-948

Porter, K. G., Sherr, E. B., Sherr, B. F., Pace, M., Sanders, R. W (1985). Protozoa in planktonic food webs. J. Protozool. 32 $409-415$

This article was submitted to the editor
Sanders, R. W., Porter, K. G. (1986). Use of metabolic inhibitors to estimate protozooplankton grazing and bacterial production in a monomictic eutrophic lake with an anaerobic hypolimnion. Appl. environ. Microbiol. 52: 101-107

Scavia, D. (1988). On the role of bacteria in secondary production. Limnol. Oceanogr. 33: 1220-1224

Shaikh, E. A., Roff, J. C., Dowidar, N. M. (1986). Phytoplankton ecology and production in the Red Sea off Jiddah, Saudi Arabia. Mar. Biol. 92: 405-416

Sherr, B. F., Sherr, E. B. (1984). Role of heterotrophic protozoa in carbon and energy flow in aquatic ecosystems. In: Klug, M. J., Reddy, C. A. (eds.) Current perspectives in microbial ecology. American Society for Microbiology, Washington, D.C., p. $412-423$

Sherr, B. F., Sherr, E. B., Andrew, T L., Fallon, R. D., Newell, S. Y (1986). Trophic interactions between heterotrophic Protozoa and bacterioplankton in estuarine water analyzed with selective metabolic inhibitors. Mar. Ecol. Prog. Ser. 32: $169-179$

Sherr, E. B. (1988). Direct use of high molecular weight polysaccharide by heterotrophic flagellates. Nature, Lond. 335: 348-351

Sherr, E. B., Sherr, B. F., Paffenhöfer, G.-A. (1986). Phagotrophic Protozoa as food for Metazoans: a 'missing' trophic link in marine pelagic food webs? Mar. Microb. Food Webs 1: $61-80$

Sieburth, J. McN., Smetacek, V., Lenz, J. (1978). Pelagic ecosystem structure: heterotrophic compartments of the plankton and their relationships to plankton size fractions. Limnol Oceanogr. 23: 1256-1263

Siedler, G. (1969). General circulation of water masses in the Red Sea. In: Degens, E. T., Ross, D. A. (eds.) Hot brines and recent heavy metal deposits in the Red Sea. Springer. Berlin, p. 131-137

Simon, M., Azam, F. (1989). Protein content and protein synthesis rates of planktonic marine bacteria. Mar. Ecol. Prog. Ser. 51: 201-203

Strayer, D. (1988). On the limits to secondary production. Limnol. Oceanogr. 33: 1217-1220

Thiel, H., Weikert, H. (1984). Biological oceanography of the Red Sea oceanic system. Deep Sea Res, 31: 829-831

Weikert, H. (1982). The vertical distribution of zooplankton in relation to habitat zones in the area of the Atlantis II deep, central Red Sea. Mar. Ecol. Prog. Ser. 8: 129-143

Weisse, T (1989). Trophic interactions among heterotrophic microplankton, nanoplankton and bacteria in Lake Constance. Hydrobiologia, (in press)

Wikner, J., Andersson, A., Normark, S., Hagström, ^. (1986) Use of genetically marked minicells, a probe to measure predation in aquatic environments. Appl.. environ. Microbiol. $52: 4-8$

Wikner, J., Hāgström, A., Rassoulzadegan, F. (1987). Short term changes in bacterivore activity balances bacterial production in the ocean. EOS 68: 17982

Wishner, K. F. (1980). The biomass of deep-sea benthopelagic plankton. De:ep Sea Res. 27: 203-216

Wright, R. T, Coffin, R. B. (1984). Measuring microzooplankton grazing on planktonic bacteria by its impact on bacterial production. Microb. Ecol. 10: 137-149

Manuscript first received: November 24, 1988

Revised version accepted: May 25, 1989 